\title{
REVIEW ON HEMIGRAPHIS COLORATA AND ITS PROPERTIES
}

\author{
Sandhiya . S, Sabarinath .K, Ishwarya .R, Logeshwaran .V, Kousalya.N, \\ Post graduate students \\ Department of Biotechnology, Dr. N.G.P. Arts and Science College,
} Coimbatore-48

Arun . P

Assistant professor

Department of Biotechnology, Dr. N.G.P. Arts and Science College,

Coimbatore-48

\begin{abstract}
-
Hemigraphis coloratais a medicinal plant originates from the tropical regions of kerala and its native is from the sides of Malesia. It is a perennial herb mostly grown as ornamental plant. It is a tribal plant of the tribes of Kerala. It is commonly called as "murikooti or muryanpacha".H.coloratais used as herbal ointments to cure cut wounds, ulcers and most importantly bleedings. It has many valuable properties like anti-microbial and antidiabetic activities. It acts as an anti oxidant and exhibit free radical scavenging activity. This review paper is intended to sum up and gather all the important information about the pharmacological effects and the activities of H.colorata.
\end{abstract}

Keywords - Hemigraphis colorata, natural dye for solar energy conversion, pharmacological properties.

\section{INTRODUCTION}

India has wide variety of herbal plants which are used as medicines by the peoples to cure diseases these types of medications used by us is known as phytopharmaceuticals or phytotherapeutic agents. In such wide varieties of herbal plants in this paper we are going to know about the properties of Hemigraphis Colorata.

Hermigraphis colorata is an herbal plant mostly grown as an ornamental plant. Its origin is from tropical

Table: 1

\begin{tabular}{|l|l|l|l|l|l|l|l|l|l|}
\hline Compounds & Hexane & benzene & $\begin{array}{l}\text { Petroleum } \\
\text { ether }\end{array}$ & chloroform & Ethanol & methanol & acetone & aqueous \\
\hline Alkaloid & - & - & - & + & - & + & - & + \\
\hline Phenol & - & + & + & + & + & - & + & + \\
\hline Flavanoids & - & - & + & + & + & - & - & + \\
\hline Saponins & - & + & + & + & + & - & - & - \\
\hline Steroids & + & + & + & + & + & + & + & + \\
\hline Tannins & - & + & + & - & + & + & + & - \\
\hline Carbohydrate & + & + & - & + & + & + & + & + \\
\hline
\end{tabular}

regions of Malay Archipelago [1] and its native is from the South East Asia and also the cascades over Northern Queensland [2]. The characterizations of Hemagraphis colorata are as follows; It is a perennial herbal plant from about 15 to $30 \mathrm{~cm}$. It is a prostate herb which has toothed leaves and purple citations in leaves. The colour of the leaves are greyish green and has small white flowers. The flowers are white in colour and has five lobes. It is bell shaped.

The phytopharmaceutical properties of Hemigraphis colorata are: It is most commonly used to treat bleeding wounds, cuts and inflammation and internally used to cure ulcers, haemorrhoids, diuretics, gall stones, anemia and diabetes mellitus [3].

Scientific classification

\section{PLANTPROFILES}

$\begin{array}{ll}\text { Kingdom } & \text { : Plantae } \\ \text { Order } & \text { : Lamiales } \\ \text { Family } & : \text { Acanthaceae } \\ \text { Genus } & \text { : Hemigraphis } \\ \text { Species } & \text { : Colorata }\end{array}$

II. PHYTOCHEMICAL ANALYSIS

The Phytochemical characteristics of Hemigraphis colorata was studied under many activities like alkaloids, phenols, flavanoids, saponins, steroids, tannins and carbohydrates. The results revealed that there is a presence of active compounds and phytoconstituents. The exctract of the plant exhibits medicinal and physiological properties. The 


\section{International Journal of Engineering Applied Sciences and Technology, 2019 \\ Vol. 4, Issue 7, ISSN No. 2455-2143, Pages 336-338 \\ Published Online November 2019 in IJEAST (http://www.ijeast.com)}

results which are given in table $1 .[4,5,6,7,8]$

+ indicates presence, - indicates absence

These above result shows there are secondary metabolites present with curative property.

\section{COMMON USES}

Hemigraphis colorata is a medicinal plant which is very commonly used by the people to cure cuts, bleeding wounds and internally ulcers, heamorhoids, anemia, dysentery and diabeteus mellitus[3]. The plants are grounded into fine paste and applied on the wounds.

\section{PHARMACOLOGICAL STUDIES}

\section{Wound healing activity:}

Hemigraphis colorata is considered to be a medicinal plant which heals bleeding wounds and cuts. The juices of the leaves are applied to cut wounds which cures the wounds[9]. The studies have been made on wound healing studies with help of formulating hydrogel by using polymer carbopol 934[10]. These activity was studied in mice by topical application by invitro studies[1]. Silver nano particle has been synthesized from H.colorata and developed into GCG scaffold. The physical cross linking scaffold showed MTT cell proliferation and invitro wound healing assay proved that scaffolds are non cytotoxic, promote cell adhesionand have potent wouns healing activity[12].

\section{Anti inflammatory activity:}

The oral administration of leaf suspension and topical application were devoid of anti inflammatory in mice [10]. Also the methanolic extract of H.colorata showed anti inflammatory activity in rats [13]. Ethyl acetate extract of H.colorata showed anti inflammatory avtivity and inhibits 5LOX. COX-1,2 enzymes which are responsible inflammation in dose dependent manner in human keratinocyte cell line (HaCaT cells)[14]. In the invitro experiment, acetone extract showed $43 \%$ and $48 \%$ of inhibition of anti inflammatory activity [15].

\section{Anti bacterial and anti microbial activity:}

Theaqueus extract of H.colorata showed Anti bacterial and anti microbial activity against staphylococcus aureus and psuedomonasspeicies [16]. The cotton fibres were finished with the exctracts of H.colorataand three other herbal plant showed anti microbial activity against Eschericia coliand staphylococcus aureus [17].

\section{Anti diabetic activity:}

Anti diabetic activity was studied using H.colorata in rats. The study showed that $n$-hexane and ethanol extracts of the whole plant were found to lower the blood glucose levels $n$ rats. The presence of coumarins and steroids in the plant exctract is responsible for anti diabetic activity[18].

\section{Miscellaneous activity:}

Further Hemigraphis coloratais extracted to make natural dyes which is used as a photosenstizer in dye sensitized solar cells along with $\mathrm{TiO}_{2}$ nano particles. Photovoltaic property of H.colorata showed an energy conversion efficiency of about $0.0065 \%$. The higher concentration of anthocyanin is responsible for photovoltaic property.

Chloramphenicol and ciproflaxin are antibiotics were used in anti bacterial assays of methanolic extract of Hemigraphis to treat UTI patients [19].

\section{CONCLUSION}

Hemigraphis colorata is an herbal plant which is used as a medication for curing cut wounds and bleeding. It is a tribal plant of Kerala. It has many properties and contains secondary metabolite and bio active compounds. The properties of H.colorataare anti microbial activity, anti diabetic activity, wound healing activity and acts as a natural dye for solar energy conversion. Species of Hemigraphis are used as an antibiotic to treat UTI patients. Thus Hemigraphis colorata has many useful properties. This plant grows perennially and can be easily grown. The studies on H.colorata paves way for new pharamacological studies and Phytochemical studies.

\section{ACKNOWLEDGEMENT}

The author express their gratitude towards the host Institution Dr.N.G.P. Arts and Science college, Management, Principal, Deans, Head of the department, guide and other all other staffs of Department of biotechnology for rendering all the facilities and support. Communication no: DrNGPASC 2019-20 BS016.

\section{REFERENCE}

[1] Radhika P. V.* and Arun Kumar K. V. Hemigraphis colorata (blume) and Glycyrrhiza glabra (linn) hydrogel for wound healing and anti-inflammatory activity, Department of Pharmaceutics, Rajiv Gandhi Institute of Pharmacy Trikaripur (P.O) Kasaragod, Kerala, 671310. World journal of pharmacy and pharmaceutical sciences SJIF Impact Factor 6.647Volume 6, Issue 12, 902-923 ISSN 2278 - 4357.

[2] M. Devipriya (2013). Review on pharmacological of Hemigraphis colorata (Blume).International journal of herbal medicine,; 1(3): 120-121.

[3] Gayathri V, Lekshmi P, Padmanabhan RN (2011). Antidiabetes and hypoglycaemic properties ofHemigraphiscolorata in rats. International J.Pharam Science.; 4(2):224-328. 


\section{International Journal of Engineering Applied Sciences and Technology, 2019 \\ Vol. 4, Issue 7, ISSN No. 2455-2143, Pages 336-338 \\ Published Online November 2019 in IJEAST (http://www.ijeast.com)}

[4] Yadav, RNS and Munin Agarwala (2011). Phytochemical analysis of some medicinal plants.Journal of Phytology.; 3(12): 10-14.

[5] Rathish Nair, Sumitra VC (2007). Antibacterial activities of some medicinal plants of the western region of India. Turk J; 31:231-236.

[6] AbeerTemraz and Walid $\mathrm{H}$ EL- Tantawy. Characterization of antioxidant activity ofextract from Artemisia vulgaris. Pak. J, Pharm. 2008; 21:321-326.

[7] Gutfinger $\mathrm{T}$ (1981), poly Phenol in Olive oils. LAm.OilChem.Soc.; 58:966-968.

[8] Reshma Rajeev K, Sincy Joseph, Neethu Ek, Kavya V, anjali Km, M Suga Bharathi (2018). Preliminary Phytochemical and bio chemical analysis of Hemigraphis colorata H.G. Hallier. Coimbatore, Tamilnadu IJRPPS, (Volume 3, issue 3: 05-09).

[9] VP Silja, K samitha Varma \& KV Mohanan, Ethnomedical plant knowledge of the mullu kuruma tribe of wayanad distirct, Kerala. Calicut Kerala-35, 2008 vol. 7(4) 604-612.

[10]A. Subramoniam, D. A. Evans, S. Rajasekharan, G. Sreekandannair, effect of hemigraphis colorata (blume) h. G. Hallier leaf onWound healing and inflammation in mice.Thiruvananthapuram, Kerala. IJP 2001;33:283-285.

[11] V.D.Jadhav, G.Talele Swati, A.BakliwalAkshada and G.N Chaudhari (2015). Formulation And Evaluation Of Herbal Gel Containing Leaf Extracts Of TridaxProcumbens. Journal of Pharmaceutical and Bio Sciences, ; 3(1): 65-72.

[12]Liji Thomas and Saleena Mathew (2016), Development of glycosaminoglycan scaffold integrated with herbal nano particles for wound healing, School of fisheries, Kochi-16, IJAPSA 280-290, ISSN 2394-5532.

[13]Bhagyalakshmi Chengattu Prakashbabu1, Deepthi Vijay1, Saju George1,Sameer Kodiyil1, Suresh Narayanan Nair1*, Ajithkumar Karaparambil Gopalan2, Sanis Juliet1 and Reghu Ravindran (2017), Wound Healing and Anti-Inflammatory Activity of Methanolic Extract of Gmelina arborea and Hemigraphis colorata in Rats. College of Veterinary and Animal Sciences, Pookode, Wayanad- Kerala-673576, India. ISSN 23197706, Vol 6(8), 3116-3122.

[14] Arun K. Kashyap, Nimmanapalli P. Reddy, Chaitanya R. K and Roy Karnati* , (3 October, 2013) Ethyl acetate extract of Hemigraphis colorata leaves shows antiinflammatory and wound healing properties and inhibits 5-lipoxygenase and cyclooxygenase-1and 2 enzymes.University of Hyderabad, PO Central
University, Hyderabad, 500046, India. Vol. 7(37), pp. 2783-2791,: 10.5897/JMPR2013.5184 ISSN 1996-0875 C2013 Academic Journals.

[15] Shahid Adangapurath and Sudeesh sudhakaran (2018), Anti- inflammatory potential of flavonoid from Hemigraphis colorata. Int.J. of life science,; 6(2):569574' ISSN 2320-7817.

[16]Dhinesh, Khamarunnisa V, Nabla Meherry, Shaheena A, and Nithya Jayan (January 2016), Anti microbial properties and Phytochemical screening of medicinal plants against clinical pathogens by in-vitro methods. IJRSR, Vol 7(1), 8167-8171; ISSN 0976-3031.

[17] Shabrin Farhana G*1, Palaniswamy NK 2 (2018), Carboxymethylation $(\mathrm{cm})$ of natural fibres: investigating the moisture Absorbency and evaluating antimicrobial property of herbal finished cm-fibres.1Sr.Faculty, FDDI, Ministry of Commerce and Industry, Govt of India, Kancheepuram, Tamil Nadu, India. 2 Professor, Department of Textile and Engineering, College of Engineering and Technology, University of Aksum, Ethiopia.Int.J.Res. Ayurveda pharm. 9(3)

[18] Gayathri.V, Lekshmi. P, Padmanabhan R.N* (2012),* Department of Biochemistry, Government Medical College, Trivandrum, Kerala, India 695011 , \# Department of Pathology, Government Medical College, Kottayam, Kerala, India 686 008. IJPPS Vol 4(2), ISSN 0975-1491.

[19] V.G. Nandakumara, S. Suresha, C.O. Sreekalab, S.K. Sudheera, V.P. Mahadevan Pillaia*, Hemigraphis colorata as a natural dye for solar energy conversion.a Department of Optoelectronics, University of Kerala, Kariavattom, Thiruvananthapuram -695581, Kerala, India.School of Biotechnology, Amrita Vishwa Vidyapeetham , Amrithapuri Campus, Kollam-690525, Kerala, India.

[20] Rashidul Islam, Shoshi Prasad Shila, Md. AkterHossaina, Md. ArifulIslama, Debasish Kumer Paula, Abdullah-AlJubayerb, Soma Kunduc, Md.SarafatAlib, Dababrata Paul (april 2019), Study on Hemigraphis hirta as an Alternative to Antibiotics against Bacteria causing Urinary Tract Infection. North American Academic Research. Vol 2(4);:66-75. 